\title{
Alat Pengukur Debit Air dan Harga Menggunakan Mikrokontroler Arduino Uno Berbasis IoT
}

\author{
Widyo Ari Utomo*1, Agung Nugroho ${ }^{2}$, Muslim Nugroho ${ }^{3}$ \\ 1,3Program Studi Sistem Komputer, STMIK AUB, Surakarta, Indonesia \\ ${ }^{2}$ Program Studi Teknik Komputer, STMIK AUB, Surakarta, Indonesia \\ e-mail: *11widyoari@stmik-aub.ac.id, ${ }^{2}$ agung_new@stmik-aub.ac.id, \\ ${ }^{3}$ moeslim212@gmail.com
}

\begin{abstract}
Abstrak
Seiring dengan perkembangan teknologi informasi telah melahirkan smartphone yang memiliki kemampuan seperti computer. Di dalam PAMSIMAS, samrtphone dapat memberikan kenyamanan atau kemudahan dalam monitoring penggunaan debit air pada masyarakat yang menggunakan air PAMSIMAS. Hasil yang dicapai adalah meningkatkan aspek kenyamanan dan kemudahan yang umumnya digunakan pada masyarakat awam dalam monitoring penggunaan debit air setiap bulannya, dimana yang sebelumnya menggunakan meteran yang tidak semua orang bisa membacanya, dan rangkaian ini dapat bekerja dengan water flow sensor pada mikrokontroler arduino uno. Sistem kerja sensor ini adalah dengan memanfaatkan fenomena efek hall. Efek hall ini didasarkan pada efek medan magnetik terhadap partikel bermuatan yang bergerak sehingga didapatkan nilai frekuensi. Frekuensi kemudian dikalkulasikan menjadi kecepatan laju air dan volume total. Hasil pengukuran kemudian ditampilkan pada LCD $16 \times 4$ karakter berupa laju air dan volume total. Kemudian hasil tersebut di kirimkan ke smartphone petugas PAMSIMAS dengan menggunakan wemos dl mini ke aplikasi blynk. Dengan adanya alat tersebut diharapkan dapat memudahkan PAMSIMAS untuk memonitoring secara online sehingga dapat dilakukan kapan saja dan dimana saja serta mempermudah pengolahan data dan laporan.
\end{abstract}

Kata kunci-Monitoring Penggunaan Debit Air, Water Flow Sensor, PAMSIMAS

\begin{abstract}
Along with the development of information technology has given birth to smartphones that have capabilities like computers. At PAMSIMAS, a smartphone can provide convenience or use in monitoring the use of discharge water for people using PAMSIMAS water. The results achieved are increasing the comfort and convenience commonly used by the general public in monitoring the use of water discharge every month, where previously using a meter that everyone can read, and this circuit can work with a water flow sensor on the Arduino Uno microcontroller. This sensor work system is to utilize the hall effect phenomenon. The hall effect is based on the effect of the magnetic field on moving particles so that they get the frequency value. The frequency is then calculated to be the air velocity and total volume. The measurement results then occur on the 16x4 LCD with the character of air velocity and total volume. Then the results are sent to the PAMSIMAS officer smartphone using wemos d1 mini to the blynk application. This tool is expected to make it easier for PAMSIMAS to monitor online so that it can be done anytime and anywhere and facilitate data processing and reports.
\end{abstract}

Keywords - Monitoring the Use of Water Discharge, Water Flow Sensor, PAMSIMAS 


\section{PENDAHULUAN}

Air merupakan suatu senyawa netral yang keberadaannya sangat penting bagi seluruh makhhuk hidup di bumi. Semua makhluk hidup memiliki ketergantungan tinggi. Merupakan zat pelarut penting bagi makhluk hidup karena berperan dalam proses metabolisme. Khususnya bagi manusia membutuhkan air untuk keperluan sehari-hari seperti halnya minum, mencuci, mandi, dan lain sebagainnya, dalam pengelolahan air terdapat perusahaan yang bergerak pada bidang penyaluran air bersih yaitu Penyediaan Air Minum dan Sanitasi Berbasis Masyarakat dengan singkatan PAMSIMAS.

PAMSIMAS atau Penyediaan Air Minum dan Sanitasi Berbasis Masyarakat merupakan salah satu unit usaha milik pemerintah, yang bergerak dalam distribusi air bersih bagi masyarakat umum. Terdapat juga di setiap provinsi, kabupaten, dan kotamadya di seluruh Indonesia, dan merupakan perusahaan daerah sebagai sarana penyedia air bersih yang diawasi dan dimonitor oleh pegawai.

Perusahaan air minum yang dikelola masyarakat secara modern sudah ada sejak zaman penjajahan Belanda pada tahun 1920an dengan nama Waterleiding sedangkan pada pendudukan Jepang perusahaan air minum dinamai Suido Syo. Penghitungan pembayaran dilakukan oleh pihak.

PAMSIMAS menggunakan alat yang disebut dengan meteran berguna untuk menghitung debit dan mengetahui berapa tagihan air digunakan. Namun dalam pelaksanaan monitoring sering sekali terjadi kesalahan dalam pencatatan penggunaan air pada sensor penghitungan berbeda sedangkan pada pemakaian sama.

Penyaluran oleh pihak PAMSIMAS diperlukan proses pengecekan atau monitoring penggunaan air ke masing-masing pelanggan setiap bulannya dan dalam pelaksanannya masih menggunakan sistem manual yaitu dengan mengirimkan petugas secara periodik untuk mendatangi secara langsung ke rumah-rumah pelanggan.

Permasalahan dalam pengontrolan petugas PAMSIMAS masih menggunakan cara manual dan petugas tidak dapat datang mengontrol kerumah-rumah mengakibatkan terlambatnya proses pencatatan maka dari pihak petugas memerlukan alat, yang diharapkan dapat mempermudah kinerja petugas PAMSIMAS. Dari permasalahan yang telah diuraikan diatas, maka penulis mengambil judul "Alat Pengukur Debit Air Dan Harga Menggunakan Mikrokontroler Arduino Uno Berbasis IoT".

\section{METODE PENELITIAN}

\subsection{Teknik Pengumpulan data}

Metode pengumpulan data adalah teknik atau cara yang dilakukan oleh peniliti untuk mengumpulkan data. Metode pengumpulan data yang digunakan penulis antara lain:

a. Observasi

Peneliti melakukan observasi dengan mengumpulkan data dan mengamati secara langsung proses pencatatan debit air pada meteran PAMSIMAS, serta masalah yang akan ditimbulkan dari sistem yang sedang dijalankan.

b. Wawancara

Peneliti melakukan wawancara terhadap petugas pengurus PAMSIMAS tentang masalah monitoring dan menentukan solusi tentang permasalah yang ada.

c. Studi Literatur

Tahapan ini peneliti mencari referensi-referensi yang relevan dengan objek penelitian. Pencarian referensi dilakukan secara online melalui jurnal online, buku dan artikel. Referensi yang dicari terkait dengan pengukuran debit air, penggunaan Arduino uno, penghitungan biaya air, water flow sensor dan wemos d1 mini yang akhirnya digunakan dalam penyusunan landasan teori, metodologi penelitian secara pengembangan alat secara langsung.

GO INFOTECH: JURNAL ILMIAH STMIK AUB Vol. 27, No. 1, Juni 2021: 25-32 


\subsection{Tahap-Tahap Penelitian}

a. Requirements Analisis

Tahap ini peneliti menganalisa tahap-tahap yang diperlukan dalam pembuatan alat sistem kendali penghitungan air pelanggan PAMSIMAS berbasis water flow sensor dan Wemos D1 mini.

b. Design

Tahapan ini peneliti melakukan perancangan alat, gambar rangkaian, flowchart terhadap solusi dari permasalahan yang ada di lingkungan sekitar yang berkaitan dengan penelitian dan dokumentasi yang dihasilkan dari tahap desain sistem ini menggunakan software Fritzing.

c. Coding

Tahap ini adalah proses penulisan program pada software Arduino IDE.

d. Testing

Tahap ini yaitu melakukan proses percobaan terhadap program yang telah dibuat. Kemudian dilakukan pengkajian ulang terhadap sistem dan alat tersebut.

e. Maintenance

Tahapan ini merupakan proses yang dapat dikatakan selesai dalam pembuatan sebuah alat dan sistem. Setelah melakukan analisa, desain dan pengkodean maka sistem dan alat yang sudah jadi akan digunakan oleh user. Dalam tahap ini juga dilakukan pengembangan alat seperti penambahan sensor dan fungsi baru dari alat.

\subsection{Diagram Blok}

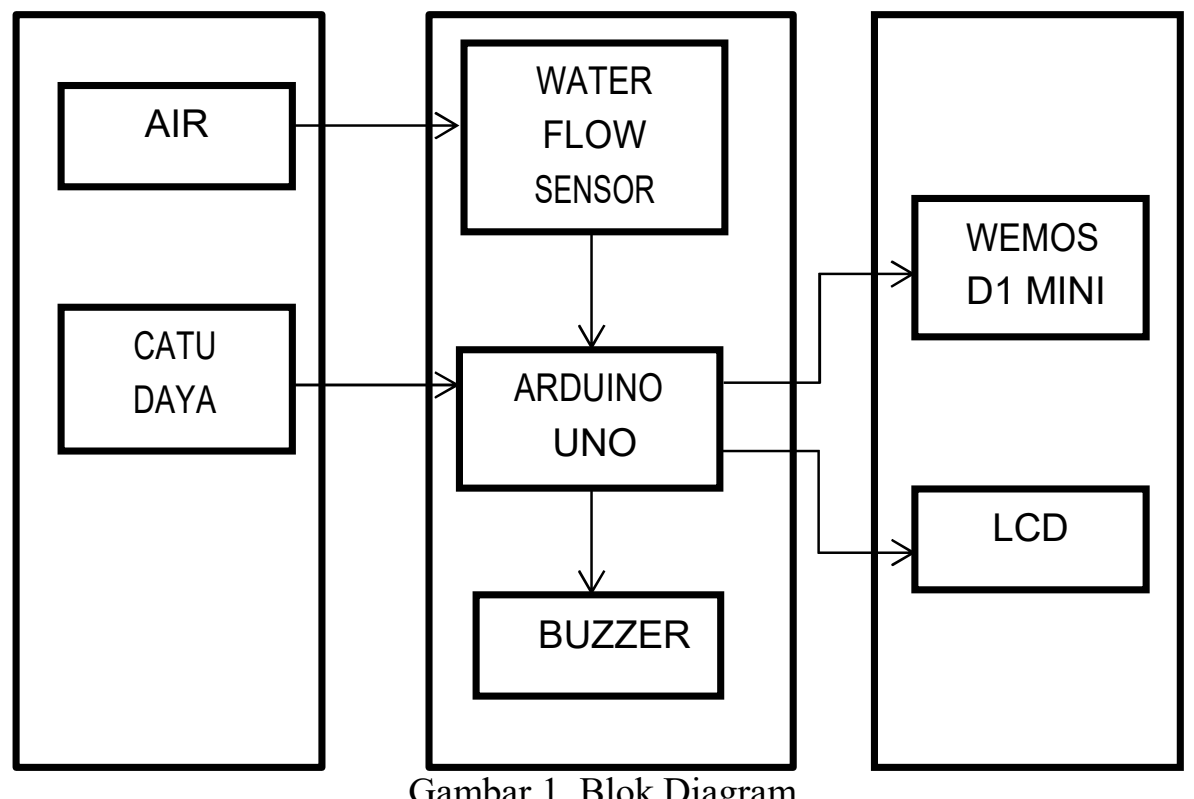

Berdasarkan Gambar 1 maka dapat diuraikan masing- masing blok fungsinya sebagai berikut:

a. Bagan Input

Bagian ini merupakan kumpulan dari beberapa inputan beban daya yang masuk ke arduino.

b. Bagan Proses

Bagian ini menggunakan arduino uno yang berfungsi sebagai pusat pengolahan data, yang tugasnnya mengolah proses masukan dan keluaran.

c. Bagan Output

Bagian ini merupakan proses keluaran dari arduino uno berupa Sim wemos d1 mini sebagai proses pengiriman pesan teks/angka dan LCD sebagai tampilan. 


\subsection{Flowchart}

Flowchart sistem dibuat untuk memudahkan dalam menggambar urutan kerja sistem kendali alat. Flowchart sistem dapat dilihat pada Gambar 2 berikut.

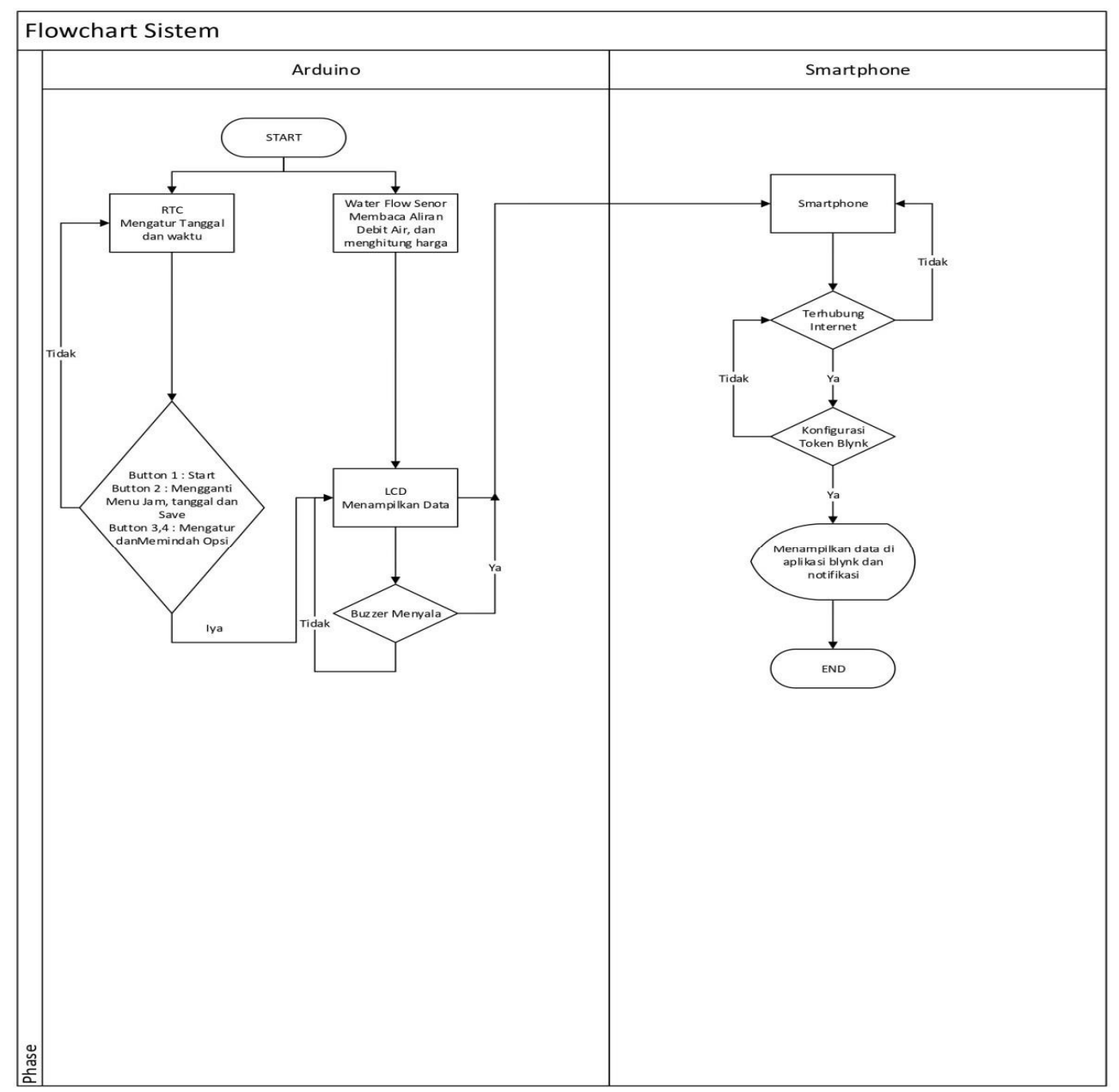

Gambar 2. Diagram Flowchart

\subsection{Perancangan Keseluruhan}

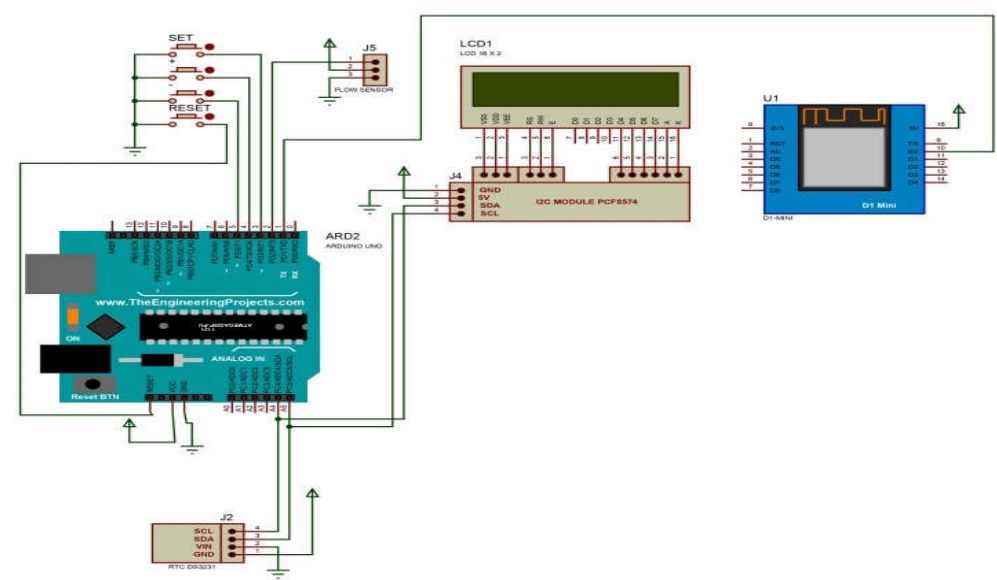

Gambar 3. Perancangan Rangkaian keseluruhan Alat Pengukur Debit Air Dan Harga Menggunakan Mikrokontroler Arduino Uno Berbasis Iot

GO INFOTECH: JURNAL ILMIAH STMIK AUB Vol. 27, No. 1, Juni 2021: 25-32 


\section{HASIL DAN PEMBAHASAN}

\subsection{Unit penelitian}

Penelitian dilakukan di desa Nglambang rt/rw 01/10 Jumapolo, Kec.Jumapolo, Kab.Karanganyar, Jawa Tengah.

\subsection{Analisa Kebutuhan Alat}

Tabel 1 Kebutuhan Alat

\begin{tabular}{|l|c|l|}
\hline Nama Komponen & Jumlah & \multicolumn{1}{|c|}{ Fungsi } \\
\hline Laptop & 1 & $\begin{array}{l}\text { Digunakan untuk memasukan program dari IDE } \\
\text { Arduino ke komponen Arduino }\end{array}$ \\
\hline Mika Acrilic & 1 lembar & $\begin{array}{l}\text { Digunakan untuk tempat atau pengemasan alat } \\
\text { keseluruhan }\end{array}$ \\
\hline Avo meter & 1 & $\begin{array}{l}\text { Digunakan sebagai penguji tegangan pada } \\
\text { komponen }\end{array}$ \\
\hline PCB & 1 & $\begin{array}{l}\text { Digunakan sebagai tempat pemasangan Arduino } \\
\text { dan komponen }\end{array}$ \\
\hline Solder & 1 & $\begin{array}{l}\text { Digunakan untuk melelehkan tenol atau timah saat } \\
\text { Penyambungan }\end{array}$ \\
\hline Tenol / Timah & $\begin{array}{l}\text { Digunakan sebagai penyambung komponen pada } \\
\text { alat }\end{array}$ \\
\hline Kabel Pelangi & 1 Meter & Digunakan unjuk penjamperan antar komponen \\
\hline Kabel konektor & 1 & Digunakan sebagai penghubung alat dengan laptop \\
\hline Gergaji & 1 & Digunakan untuk memotong Acrilik \\
\hline
\end{tabular}

\subsection{Analisa Kebutuhan Bahan}

Tabel 2 Kebutuhan Bahan

\begin{tabular}{|l|c|l|}
\hline \multicolumn{1}{|c|}{ Nama Komponen } & Jumlah & \multicolumn{1}{c|}{ Fungsi } \\
\hline Arduino Uno R3 & 1 & $\begin{array}{l}\text { Digunakan sebagai pengelola program } \\
\text { dari masing-masing komponen alat }\end{array}$ \\
\hline Water Flow Sensor seri G1/4" & 1 & $\begin{array}{l}\text { Digunakan untuk mengetahui jumlah } \\
\text { total volume air yang telah mengalir }\end{array}$ \\
\hline Wemos D1 Mini & 1 & $\begin{array}{l}\text { Berfungsi sebagai pengiriman data teks } \\
\text { atau angka }\end{array}$ \\
\hline LCD (Liquid Crystal Display) & 1 & $\begin{array}{l}\text { Berfungsi sebagai media tampilan yang } \\
\text { menggunakan kristal cair sebagai } \\
\text { tampilan suatu data, karakter, huruf } \\
\text { maupun grafis }\end{array}$ \\
\hline Buzzer & 1 & $\begin{array}{l}\text { Digunakan sebagai komponen } \\
\text { pengingat atau alarm berupa suara }\end{array}$ \\
\hline RTC (Real Time Clock) & 1 & $\begin{array}{l}\text { Digunakan sebagai pengatur waktu dan } \\
\text { hari pada tampilan LCD }\end{array}$ \\
\hline
\end{tabular}

\subsection{Pengujian Alat}

Pengujian alat diperlukan untuk melihat apakah sistem telah bekerja dengan baik. Hasil dari pengujian adalah sebagai berikut :

a. Pengujian Hari Pertama Pemasangan

Pengujian ini dilakukan dengan kondisi nilai masih 0, dapat dilihat pada Gambar 4 berikut. 
b. Pengujian Hari 12

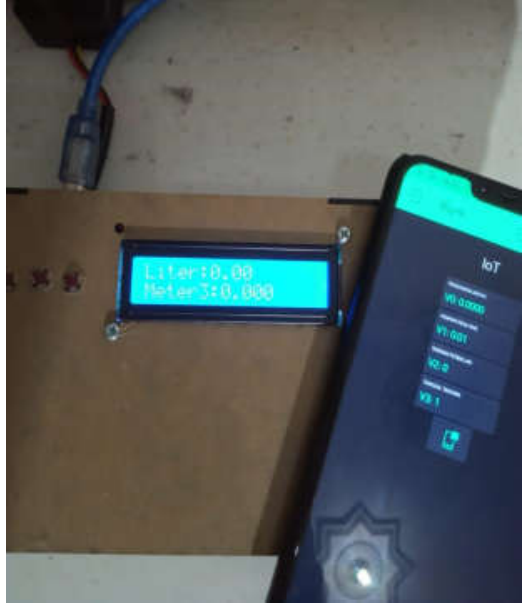

Gambar 4. Tampilan Liter dan Meter Kubik

Pengujian Gambar 5 ini dilakuan untuk mengecek apakah alat masih berfungsi atau ada komponen yang rusak.

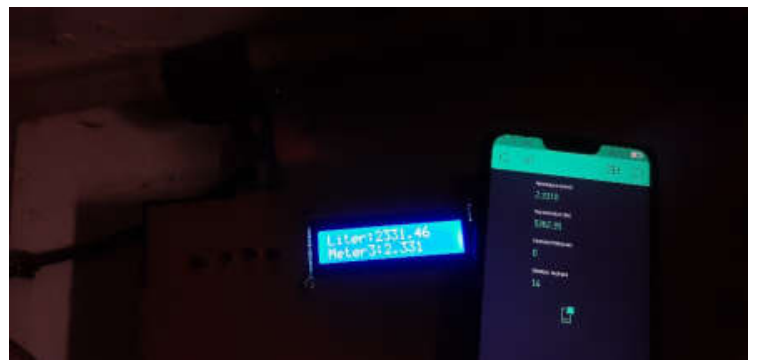

Gambar 5. Tampilan Liter dan Meter Kubik

c. Pengujian 1 Bulan

Pengujian Gambar 6 ini adalah hasil dari semua tahapan diatas terdapat fungsi notifikasi yang berhasil dan komponen yang normal tanpa ada kerusakan.

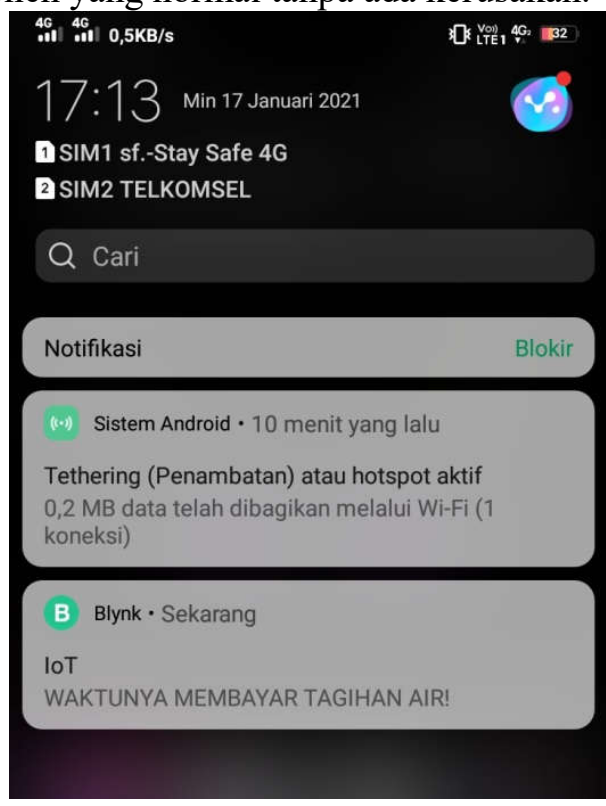

Gambar 6. Notifikasi

\subsection{Pembahasan}

Secara umum, cara kerja dari alat ini adalah water flow sensor yang berfungsi sebagai penghitung debit air yang melewati sensor tersebut, kemudian data debit air diproses melalui 
mikrokontroler Arduino Uno R3 untuk selanjutnya hasil dari proses mikrokontroler Arduino Uno R3 ditampilkan dalam LCD bersamaan dengan Buzzer yang berbunyi, memberikan peringatan kepada pelanggan apabila telah mencapai batas waktu yang ditentukan. Proses terahir adalah pengiriman tagihan pelanggan berupa pesan teks atau angka ke petugas PAMSIMAS menggunakan Wemos D1 Mini.

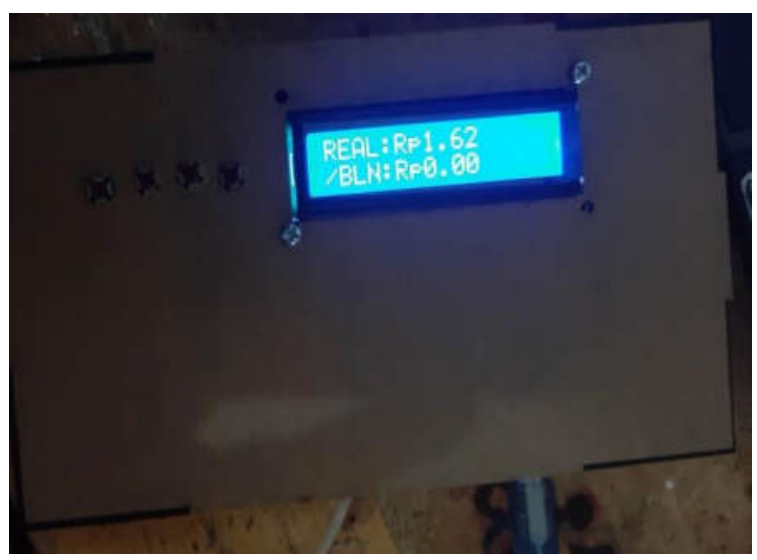

(a)

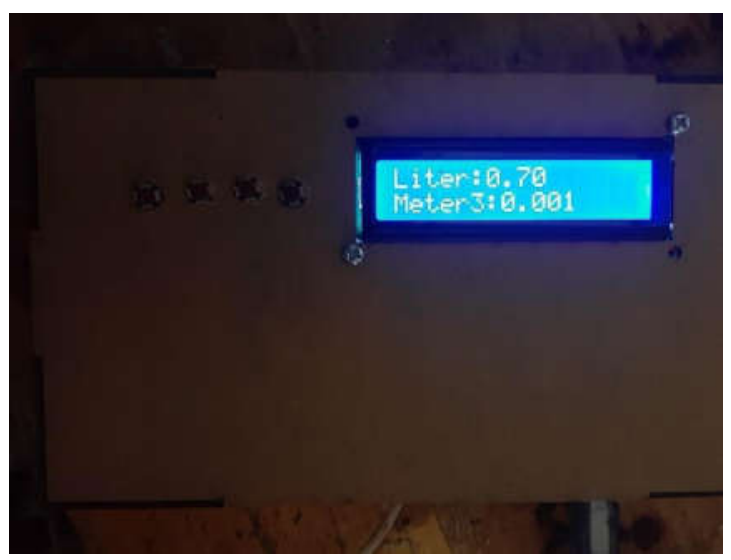

(b)

Gambar 1. (a) Tampilan Harga pada LCD, (b) Tampilan Liter dan Meter ${ }^{3}$ pada LCD

Gambar 1(b) proses pada LCD tersebut menampilkan hasil proses penghitungan setelah sensor membaca gerakan dan LCD menampilkan hasil dari pembacaan sensor, LCD menampilkan proses debit sebesar 0,001 m3 dan mendapat tagihan sebesar Rp 1.62 rupiah.

\section{KESIMPULAN}

Alat ini telah bekerja sesuai fungsinya diprogram menggunakan Bahasa $\mathrm{C}$, berbantuan Arduino IDE. Sebagai alat pengukur debit air dan harga menggunakan mikrokontroler arduino uno berbasis IoT. Water flow sensor yang mengirim data dari debit air yang mengalir dan di hitung di arduino uno R3 kemudian di tampilkan di LCD serta untuk wemos d1 mini mengirimkan data ke smartphone dengan aplikasi blynk. Untuk water flow sensor terpisah dari kotak yang berisi elektronik dan pada water flow sensor ini di pasang di antara paralon utama ke arah tandon air.

\section{SARAN}

Berikut beberapa saran yang diharapkan dalam pengembangan untuk kedepannya antara lain: alat ini belum ada penyimpanan energi listrik, jadi jika daya listrik mati alat akan mati. Jadi bisa ditambahkan alat penyimpan daya listrik. Alat ini bisa di tambahkan database jadi runtutan data perbulan tersimpan di database tersebut.

\section{DAFTAR PUSTAKA}

[1] Amin Suharjono, L. N. 2015. Aplikasi Sensor Flow Water Untuk Mengukur Penggunaan Air Pelanggan Secara Digital Serta Pengiriman Data Secara Otomatis Pada PDAM Kota Semarang. Semarang.

[2] Arif., A. 2015. Perancangan Sistem Informasi Debit Air Berbasis Arduino uno.

[3] Bain, A. \&. 2017. Sistem Kendali dan Penghitungan Biaya Air PDAM Menggunakan Watter Flow Sensor.

[4] Chaerunnissa, C. 2014. Partisipasi Masyarakat Dalam Program Penyediaan Air Minum Dan Sanitasi Berbasis Masyarakat (Pamsimas) Di Kabupaten Brebes (Vol. 5). Brebes. 
[5] Hadi Wahyono, F. 2017. Persepsi Masyarakat Mengenai Kinerja Pelayanan PAMSIMAS di Kota Semarang (Vol. 13). Semarang.

[6] Handoko, P. 2017. Sistem Kendali Perangkat Elektronika Monolitik Berbasis Arduino Uno R3. Jakarta.

[7] Harrizki Arie Pradana, R. 2014. Rancang Bangun Aplikasi Monitoring Pengguna Air PDAM Berbasis Mikrokontroler Arduino Uno. SISFOKOM, 03, 60 - 66.

[8] Ilhamsyah, D. D. 2016. Prototipe Pengukur Debit Air Secara Digitaluntuk Monitoring Penggunaan Air Rumah Tangga. Coding, Sistem Komputer Untan, 4, 109 - 118.

[9] Ilhamsyah, R. D. 2015. Prototipe Sistem Keran Air Otomatis Berbasis Sensor Flowmeter Pada Gedung Bertingkat. Coding, Sistem Komputer Untan, 03, 25 - 34.

[10] M. Iqbal Ar Rasyid, M. M. 2013. Pembangunan Prototipe Sistem Pengendalian Peralatan Listrik Pada Platform Android (Vol. 04). Bandung.

[11] Mardwi Rahdriawan, M. 2013. Evaluasi Pengelolaan Program Pamsimas Di Lingkungan Permukiman Kecamatan Mijen, Semarang (Vol. 2). Semarang.

[12] Masthura, \&. A. 2018. Jurnal Ilmu Fisika dan Teknologi.

[13] Min Jiang, C. j. (2009). Seystem Infrastructure Development Life Cycle For Enterprise Computing Systems., IEEE.

[14] Musrachi, V. R. 2015. Perancangan Sistem Pengukuran dan Monitoring pemakaian Air Rumah PDAM berbasis SMS.

[15] Nuraini, R. 2017. Desk Check Table Pada Flowchart Operasi Perkalian Matriks. 10.

[16] Prasetyo Diyan Rebiyanto, A. R. 2018. Rancang Bangun Sistem Mikrokontroler dan Monitoring Kelembapan dan Temperatur Ruangan Pada Budidaya jamur Tiram Berbasis Internet Of Thing.

[17] Rina Mardiati, F. A. 2016. Rancang Bangun Prototipe Sistem Peringatan Jarak Aman pada Kendaraan Roda Empat Berbasis Mikrokontroler ATMEGA32. Bandung.

[18] Risanty, R. D. 2016. Rancang Bangun Sistem Pengendalian Listrik Ruang Dengan Menggunakan Atmega 328 dan Sms Gateway Sebagai Media Informasi.

[19] Rouf, A. 2018. Perancangan Flowmeter Ultrasonik untuk Mengukur Debit Air pada Pipa.

[20] Sabakingkin, R. 2011. Alat Ukur Volume Air dan Penghitung Tarif Pada Water Meter PDAM.

[21] Soeharwinto, A. A. 2015. Perancangan Sistem Informasi Debit Air Berbasis Arduino uno. 13,89 - 95.

[22] Sugiyono. 2016. Metode Penelitian Kuantitatif, Kualitatif Dan R\&D. Bandung.

[23] Suharjono, A. R. 2015. Aplikasi Sensor water flow untuk mengukur pengguna air pelanggan secara digital dan mengirim data secara otomatis pada PDAM.

[24] Suwandi, E. R. 2018. Sistem Kendali Air Pelanggan PDAM Berbasis Water Flow Sensor dan SMS Gateway. Surakarta.

[25] Tony Kusuma, M. T. 2018. Perancangan Sistem Monitoring Infus Berbasis Mikrokontroler Wemos D1 R2. Bandung.

[26] Tristianto, C. 2018. Penggunaan Metode Waterfall Untuk Pengembangan Sistem Monitoring Dan Evaluasi Pembangunan Pedesaan. Tanggerang Selatan.

[27] Wijayanto, D. T. 2016. Prototipe Pengukuran Debit Air Secara Digital untuk Monitoring Penggunaan Air Rumah Tangga. 